\title{
Rheological Properties of Emulsions Stabilized by Green Banana (Musa cavendishii) Pulp Fitted by Power Law Model
}

\author{
Dayane Rosalyn Izidoro $^{1 *}$, ${\text { Agnes de Paula } \text { Scheer }^{1} \text { and Maria-Rita Sierakowski }}^{2}$ \\ ${ }^{1}$ Programa de Pós-Graduação em Tecnologia de Alimentos; Setor de Tecnologia; Universidade Federal do Paraná; \\ C.P.: 19011; 81531-990; Curitiba - PR - Brasil. ${ }^{2}$ Laboratório de Biopolímeros; Departamento de Química; \\ Universidade Federal do Paraná; C. P.: 19081; 81531-990; Curitiba - PR - Brasil
}

\begin{abstract}
In this work, the rheological behaviour of emulsions (mayonnaises) stabilized by green banana pulp using the response surface methodology was studied. In addition, the emulsions stability was investigated. Five formulations were developed, according to design for constrained surfaces and mixtures, with the proportion, respectively: water/soy oil/green banana pulp: F1 (0.10/0.20/0.70), F2 (0.20/0.20/0.60), F3 (0.10/0.25/0.65), F4 (0.20/0.25/0.55) and F5 (0.15/0.225/0.625). Emulsions rheological properties were performed with a rotational Haake Rheostress 600 rheometer and a cone and plate geometry sensor (60-mm diameter, $2^{\circ}$ cone angle), using a gap distance of $1 \mathrm{~mm}$. The emulsions showed pseudoplastic behaviour and were adequately described by the Power Law model. The rheological responses were influenced by the difference in green banana pulp proportions and also by the temperatures $\left(10\right.$ and $25^{\circ} \mathrm{C}$ ). The formulations with high pulp content (F1 and F3) presented higher shear stress and apparent viscosity. Response surface methodology, described by the quadratic model,showed that the consistency coefficient $(K)$ increased with the interaction between green banana pulp and soy oil concentration and the water fraction contributed to the flow behaviour index increase for all emulsions samples. Analysis of variance showed that the second-order model had not significant lack-of-fit and a significant $F$-value, indicating that quadratic model fitted well into the experimental data. The emulsions that presented better stability were the formulations F4 (0.20/0.25/0.55) and F5 (0.15/0.225/0.625).
\end{abstract}

Keywords: green banana pulp, emulsion, rheology, response surface methodology

\section{INTRODUCTION}

Banana is one of the most important energy sources for people living in many countries, including Brazil. It is also considered fourth on world's list of most important food crops, after rice, wheat and maize (Anon, 2002). Banana is a seasonal and highly perishable fruit and is often available year around. Due to high starch concentration (over $70 \%$ of dry weight), banana processing into flour and starch are important resource for many industrial purposes (Krzysztof et al, 2003). In Brazilian scope, banana production is 7 million tons/year, which corresponds $9.3 \%$ world-wide production (FAO, 2004; IBGE, 2007). Banana is a climacteric fruit and, in Brazil, is consumed when the fruit is ripe. For this reason, high fruit quantities are lost during their commercialization due to poor postharvest handling (Izidoro, 2007). These losses can be reduced by rejected fruit processing. Green banana pulp that contains $70-80 \%$ starch on a dry weight

\footnotetext{
*Author for correspondence: dayizidoro@ufpr.br
} 
basis, a percentage comparable to corn grain endosperm (Zhang et al, 2005), can be used as industrialized products ingredient such as gelatin, cake, bread, pies, yoghurt, ice cream and mayonnaise (Valle and Camargos, 2003).

From a physical point of view, mayonnaise is an oil-in-water emulsion $(\mathrm{O} / \mathrm{W})$ and to produce a low fat mayonnaise, it is necessary to decrease the dispersed phase and to increase the water content. According to Liu et al (2007), some fat mimetics such as modified starch, inulin, pectin, microcrystalline cellulose, carrageenan gum and some thickeners are generally used to stabilize the emulsion and to increase the light mayonnaises viscosity.Mayonnaise's rheology have been investigated by several authors because of its importance for formulation selection, process conditions and quality control. Rheological properties may give a quantitative contribution to texture characterization when using different formulations. Mayonnaise shows a yield stress, a pseudoplastic behaviour and time dependent characteristics (Peressini, et al 1998; Batista et al, 2006). Power Law, Herschel-Bulkley and Casson models have been widely used to describe mayonnaise and salad dressing flow properties (Peressini et al., 1998; Guilmineau and Kulozik, 2007; Batista et al., 2006).

Response surface methodology (RSM) is an effective statistical tool and widely used in process optimization, which includes experimental design, model fitting, validation and condition optimization (Cornell, 2002). Recently many authors reported a modeling approach based on a empirical model obtained by RSM and investigated the influence of the ingredientes concentrations on a wide range of mathematical parameters (Higuti et al, 2004; Biazus et al, 2005; Ferreira et al, 2007; Haminiuk et al 2007).

In this work, emulsions samples (mayonnaises) were made with soy oil, water and green banana pulp as stabilizant agent. The stability and emulsion's rheological behaviour were studied using the Power Law model, evaluating by means of response surface methodology the influence of water, oil and green banana pulp concentrations on the rheological parameters.

\section{MATERIALS AND METHODS}

\section{Raw material characterization}

Green bananas, "Nanica" (Musa cavendishii) variety, were obtained from a Central Supply SACEASA in Curitiba-Brazil. The M.cavendishii variety was chosen due to its availability in Brazil and the accessible price at the markets. Its moisture, $\mathrm{pH}$, tritable acidity, expressed in malic acid and soluble solids were determined according to I.A.L (2005). The bananas ripeness degree was also determined by the ratio ${ }^{\circ} \mathrm{Brix} /$ titrable acidity in order to standardize the fruits ripening condition collected for this work (Izidoro, 2007).

\section{Pulp preparation}

The green banana pulp (GBP) was obtained from the green bananas $(M$. cavendishii), which were washed, cooked under pressure for about 10 minutes, drained, peeled and homogenized in a domestic blender for 5 minutes (Borges, 2003) in a proportion of 1:1 (green banana /water) in order to improve the homogenization. One pulp fraction was used for composition analysis and another one was used to prepare the emulsions.

\section{Emulsions (mayonnaise) preparation}

The formulations were prepared with the following ingredients: water, soy oil, green banana pulp (GBP), powdered mustard, vinegar and salt, according to Valle and Camargos (2003). Condiments were not added in order not to disguise the other ingredients flavours. All of these were purchased from a local supermarket. The green banana pulp, water and soy oil proportions are described in Table 1. The vinegar, salt and mustard (powder) proportions were 3.0, 1.5 and $0.5 \%$, respectively for all the samples. The emulsions were prepared using a domestic blender at a constant speed. In the first stage the oil and mustard were mixed for 1 minute. In second stage, the water, vinegar, salt and GBP were mixed for 3 minutes. The emulsions were stored in plastic recipients and kept in refrigerator at $10^{\circ} \mathrm{C}$. 


\section{Formulations and Experimental Design}

The design for constrained surfaces and mixtures module of Statistica 7.1 (Stat-Soft, Tulsa, OK, USA) was used with three variables: water, green banana pulp (GBP) and soy oil, considering that these ingredients proportions presented repercussion in the emulsion structure. Preliminary tests were carried out to establish the minimum and maximum values to the factors. The design for constrained surfaces and mixtures was applied because the factors underwent certain limitations such as (Cornell, 2002): $0 \leq$ ai $\leq$ xi $\leq$ bi $\leq 1$ $\mathrm{i}=1,2, . \mathrm{q} \quad \Sigma \mathrm{xi}=1$, where, ai $=$ upper limit and bi $=$ lower limit.

The experimental design is presented in Table 1.

Table 1- Design for constrained surfaces and mixtures augmented of seven treatments to the water, soy oil and green banana pulp mixtures.

\begin{tabular}{ccccccc}
\hline Formulations & \multicolumn{3}{c}{ Original components } & \multicolumn{3}{c}{ Pseudo-components } \\
\hline Vertex (V) Centroid (C) & X1 & X2 & X3 & X1 & X2 & X3 \\
\hline 1V (F1) & 0.10 & 0.20 & 0.70 & 0.0000 & 0.0000 & 1.0000 \\
2V (F2) & 0.20 & 0.20 & 0.60 & 0.6660 & 0.0000 & 0.3340 \\
3V (F3) & 0.10 & 0.25 & 0.65 & 0.0000 & 0.3330 & 0.6670 \\
4V (F4) & 0.20 & 0.25 & 0.55 & 0.6660 & 0.3330 & 0.0100 \\
5V(C) (F5) & 0.15 & 0.225 & 0.625 & 0.3330 & 0.1665 & 0.5005 \\
5V(C) (F5 5$)$ & 0.15 & 0.225 & 0.625 & 0.3330 & 0.1665 & 0.5005 \\
5V(C) (F5 5 ) & 0.15 & 0.225 & 0.625 & 0.3330 & 0.1665 & 0.5005 \\
\hline
\end{tabular}

Where $\mathrm{X} 1+\mathrm{X} 2+\mathrm{X} 3=1$ or $100 \%$; $\mathrm{X} 1$ = water, $\mathrm{X} 2$ =soy oil and $\mathrm{X} 3$ = green banana pulp (GBP).

The responses were the rheological parameters flow behaviour index (n) and consistency coefficient (K) according to Haminiuk et al.,(2007). These responses were fitted according to the model that showed the higher determination coefficient value and lower chi-square value $\left(\chi^{2}\right)$. To represent the fitted response values the linear, quadratic and cubic models were used (Equations 01, 02 and 03). The equations statistical significance was determined by variance analysis (ANOVA) at $5 \%$.

$\hat{\mathrm{Y}}=\mathrm{b} 1 \mathrm{X} 1+\mathrm{b} 2 \mathrm{X} 2+\mathrm{b} 3 \mathrm{X} 3$

$\hat{\mathrm{Y}}=\mathrm{b} 1 \mathrm{X} 1+\mathrm{b} 2 \mathrm{X} 2+\mathrm{b} 3 \mathrm{X} 3+\mathrm{b} 1 \mathrm{~b} 2 \mathrm{X} 1 \mathrm{X} 2+$ b1b3X1X3 + b2b3X2X3

$\hat{\mathrm{Y}}=\mathrm{b} 1 \mathrm{X} 1+\mathrm{b} 2 \mathrm{X} 2+\mathrm{b} 3 \mathrm{X} 3+\mathrm{b} 1 \mathrm{~b} 2 \mathrm{X} 1 \mathrm{X} 2+$ b1b3X1X3 + b1b2b3 X1X2X3

where: $\hat{Y}=$ estimate rheological parameters response; $\mathrm{b}=$ equation coefficients (determined according to Cornell, 2002); $\mathrm{X}=$ pseudocomponents proportions.

\section{Basic composition analysis}

Green banana pulp and formulations composition analysis (Moisture, protein, total fat, crude fibers, ash, $\mathrm{pH}$ and acidity) were determined according to I.A.L. (2005) the mineral salts (calcium, iron, magnesium, potassium and sodium) followed the methodology according to AOAC (2000).
Carbohydrates were determined by subtracting the moisture, protein, fat, crude fiber and ash sum percentages from 100\% (USP, 2007). Caloric values were determined according to Souci et al. $(2000)$, where the caloric values $=(4 X$ protein $)+$ (9X fat $)+(4 X$ carbohydrate $)$.

\section{Rheological behaviour}

Emulsions rheological properties were performed with a rotational Haake Rheostress 600 rheometer (Haake) and a cone and plate geometry sensor (60$\mathrm{mm}$ diameter, $2^{\circ}$ cone angle). The measurements were conducted using a gap distance of $1 \mathrm{~mm}$. The sample compartment was controlled at a 10 and $25^{\circ} \mathrm{C}$ temperatures using a water bath/circulator Haake DC-30 and a Haake Universal Temperature Controler system (UTC) (Haake, Karlsruhe, Germany). The $10^{\circ} \mathrm{C}$ temperature was chosen for the reason that was the refrigeration temperature and the $25^{\circ} \mathrm{C}$ has been used by authors studying the mayonnaises and fruit purées rheological behaviour (Guerrero and Alzamora, 1997; Peressini et al., 1998; Branco, 2003; Worrasinchai et al., 2006).

Each experimental run to the upward curve had the duration of $2 \mathrm{~min}$ with shear rate range from 0 to $300 \mathrm{~s}^{-1}$, and $2 \mathrm{~min}$ to the downward curve with shear rate range from 300 to $0 \mathrm{~s}^{-1}$. Both at decreasing and increasing shear rate, 25 points of shear stress were obtained resulting in a total of 50 
data points. Three runs were done for each material, and the resulting shear stress was the three experimental averages values. The experimental data were evaluated and fitted according to the rheological Power Law model (eqn 4), using the average shear stress value for each shear rate, applying the software Origin 7.0 (OriginLab Corporation, MA, USA) to obtain the rheological $(n$ and $K)$ and statistical parameters $\left(\mathrm{R}^{2}\right.$, SSR and $\chi^{2}$ ) (Haminiuk et al., 2006)

$$
\sigma=K \cdot \gamma^{n}
$$

where: $\sigma$ is the shear stress $(\mathrm{Pa}), \mathrm{K}$ is the consistency coefficient $\left(\mathrm{Pa} . \mathrm{s}^{\mathrm{n}}\right)$ and $\mathrm{n}$ is the flow behaviour index (dimensionless). The Power Law model according to Branco and Gasparetto (2003) is a simple model and has a wide technology application.

\section{Optical microscope observation}

The glassy flat was coated with mayonnaise sample and placed on Olympus model stage CH30/CH40 (Tokio, Japan). Then adjusted the focus to get clearly the view field. The mayonnaise microstructure pictures were obtained by a camera connected to the microscope (Olympus, model PM-10Ak3, Tokio, Japan). The emulsions were observed in different periods: first day, after 15 , 30,45 and 60 days.

\section{RESULTS AND DISCUSSION}

\section{Raw material characterization}

Moisture, total soluble solids ( ${ }^{\circ}$ Brix), titrable acidity and the ratio ${ }^{\circ}$ Brix/titrable acidity analysis were carried out aiming standardize the fruit ripeness degree collected for this work as presented in Table 2.

The moisture values were in agreement with Morton (1987) who found an average $70 \%$ to green banana and around $75 \%$ to ripe banana and stated that during the maturation period, the pulp moisture content increased due to the transformation with the carbohydrates. As $\mathrm{pH}$ and titrable acidity, results were in agreement with Lima et al., (2004) who studied the bananas ripeness degree. In this work, the total soluble solids values were higher then the results found by Silva et al., (2006), which found $3.20{ }^{\circ}$ Brix to green banana, $M$. sapientum variety.

Table 2 - Green bananas (raw material) physical-chemical characteristics.

\begin{tabular}{cc}
\hline Parameters & Experimental values \\
\hline Moisture $(\%)$ & $71.69 \pm 0.12$ \\
$\mathrm{pH}$ & $5.20 \pm 0.60$ \\
Total soluble solids $\left({ }^{\mathrm{o}} \mathrm{Brix}\right)$ & $5.15 \pm 0.31$ \\
Titrable acidity $(\mathrm{g} / \mathrm{mL})$ & $0.15 \pm 0.01$ \\
Ratio $\left({ }^{\circ}\right.$ Brix/titrable acidity) & 34.80 \\
\hline
\end{tabular}

* expressed in malic acid.

\section{Rheological measurements and surface response \\ The emulsions flow curves at 10 and $25^{\circ} \mathrm{C}$ are shown in Figs 1 and 2. Marked points represent the rheogram's experimental data up and down values. It could be observed that the flow behaviour was affected by temperature, which was in agreement with Guerrero and Alzamora (1997) and Haminiuk et al. (2007) studying fruit purées and pulps flows.}

According to flow behaviour index data (Tables 3 and 4) all the samples showed shear-thinning (pseudoplastic) behaviour $(n<1)$ for both the temperatures. Pseudoplastic behaviour was found in previous studies performed with mayonnaises (Ma and Barbosa-Cánovas, 1995; Worrasinchai et al., 2006; Batista et al., 2006) and with bananas purées (Guerrero and Alzamora, 1997). According to Krokida et al, (2001), the flow behaviour index (n) is slightly affected by the temperature, with a small increase at high temperatures. 


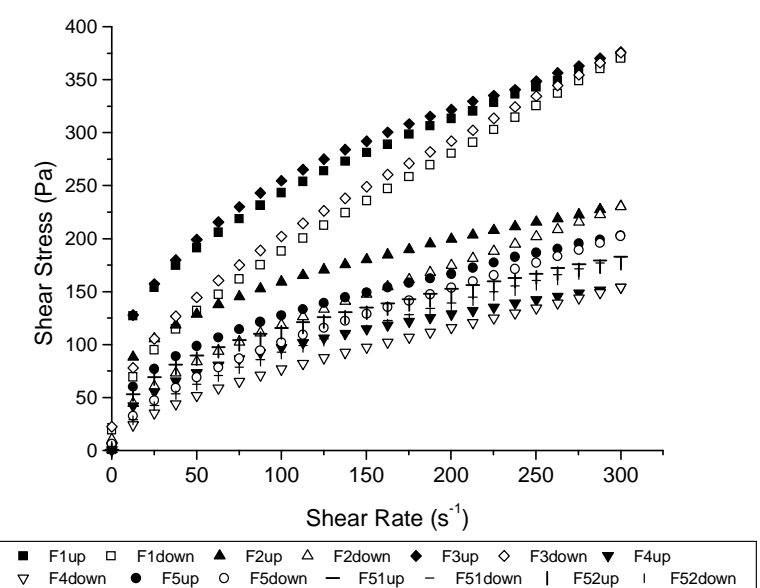

Figure 1 - Emulsions samples flow curves fitted by Power Law model at $10^{\circ} \mathrm{C}$.

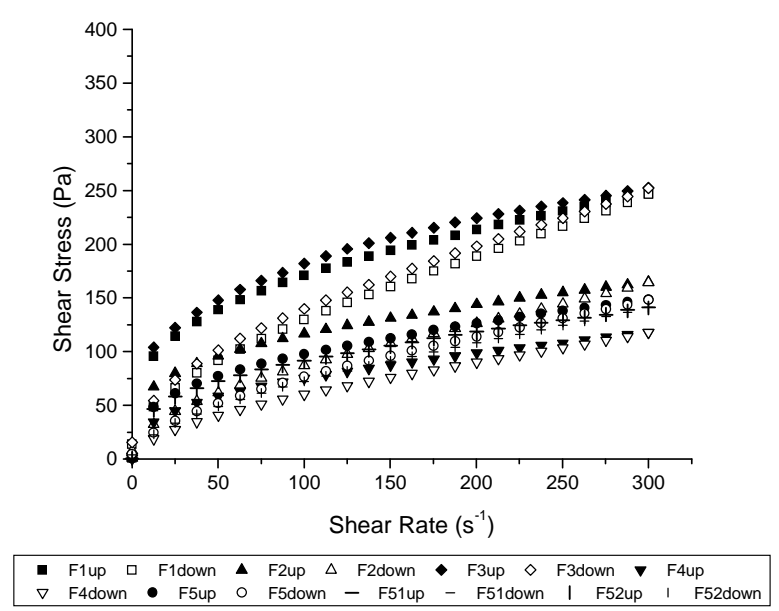

Figure 2 - Emulsions samples flow curves fitted by Power Law model at $25^{\circ} \mathrm{C}$

Table 3 - Power Law model parameters at $10^{\circ} \mathrm{C}$.

\begin{tabular}{lccccc}
\hline \multicolumn{1}{c}{$\begin{array}{c}\text { Formulations } \\
\text { (water/oil/GBP) }\end{array}$} & $\begin{array}{c}\text { Consistency } \\
\text { coefficient K } \\
(\text { Pa.s } \mathbf{n})\end{array}$ & $\begin{array}{c}\text { Flow behaviour index n } \\
\text { (dimensionless) }\end{array}$ & SSR & $\mathbf{R}^{\mathbf{2}}$ & $\mathbf{X}^{\mathbf{2}}$ \\
\hline F1(0.10/0.20/0.70) & $26.668 \pm 0.450 \mathrm{a}$ & $0.457 \pm 0.015 \mathrm{a}$ & 1.121 & 0.990 & 29.162 \\
F2(0.20/0.20/0.60) & $10.856 \pm 0.352 \mathrm{~b}$ & $0.485 \pm 0.011 \mathrm{a}$ & 0.770 & 0.991 & 3.473 \\
F3(0.10/0.25/0.65) & $31.750 \pm 0.211 \mathrm{c}$ & $0.429 \pm 0.012 \mathrm{a}$ & 0.844 & 0.989 & 13.239 \\
F4(0.20/0.25/0.55) & $8.658 \pm 0.043 \mathrm{~d}$ & $0.501 \pm 0.010 \mathrm{a}$ & 0.212 & 0.991 & 1.484 \\
F5(0.125/0.225/0.625) & $20.060 \pm 0.159 \mathrm{e}$ & $0.424 \pm 0.013 \mathrm{a}$ & 0.787 & 0.989 & 11.137 \\
F5 $(0.125 / 0.225 / 0.625)$ & $20.108 \pm 0.042 \mathrm{e}$ & $0.423 \pm 0.011 \mathrm{a}$ & 0.799 & 0.989 & 10.327 \\
F5 $(0.125 / 0.225 / 0.625)$ & $20.856 \pm 0.350 \mathrm{e}$ & $0.423 \pm 0.012 \mathrm{a}$ & 0.747 & 0.989 & 9.953 \\
\hline
\end{tabular}

Mean \pm SD values followed by the same letter in each column are not significant different by Tukey's test.

SSR - Sum of squared residuals. $\mathrm{R}^{2}$ - Determination coefficient. $\mathrm{X}^{2}$ - Chi-square. 
Table 4 - Power Law model parameters at $25^{\circ} \mathrm{C}$.

\begin{tabular}{lccccc}
\hline $\begin{array}{c}\text { Formulations } \\
\text { (water/oil/GBP) }\end{array}$ & $\begin{array}{c}\text { Consistency } \\
\text { coefficient K } \\
\left(\text { Pa.s }^{\mathbf{n}} \text { ) }\right.\end{array}$ & $\begin{array}{c}\text { Flow behaviour index n } \\
\text { (dimensionless) }\end{array}$ & SSR & $\mathbf{R}^{\mathbf{2}}$ & $\mathbf{X}^{\mathbf{2}}$ \\
\hline F1(0.10/0.20/0.70) & $22.475 \pm 0.347 \mathrm{a}$ & $0.415 \pm 0.021 \mathrm{a}$ & 0.785 & 0.989 & 10.158 \\
F2 (0.20/0.20/0.60) & $9.594 \pm 0.173 \mathrm{~b}$ & $0.467 \pm 0.011 \mathrm{a}$ & 0.291 & 0.990 & 2.074 \\
F3(0.10/0.25/0.65) & $27.487 \pm 0.443 \mathrm{c}$ & $0.386 \pm 0.012 \mathrm{a}$ & 0.612 & 0.988 & 4.862 \\
F4(0.20/0.25/0.55) & $7.336 \pm 0.391 \mathrm{~d}$ & $0.483 \pm 0.054 \mathrm{a}$ & 0.188 & 0.991 & 1.001 \\
F5(0.125/0.225/0.625) & $16.049 \pm 0.240 \mathrm{e}$ & $0.402 \pm 0.030 \mathrm{a}$ & 0.529 & 0.989 & 4.635 \\
F5 $(0.125 / 0.225 / 0.625)$ & $16.551 \pm 0.223 \mathrm{e}$ & $0.399 \pm 0.013 \mathrm{a}$ & 0.562 & 0.989 & 4.113 \\
F5 $_{2}(0.125 / 0.225 / 0.625)$ & $16.195 \pm 0.261 \mathrm{e}$ & $0.402 \pm 0.050 \mathrm{a}$ & 0.547 & 0.989 & 4.551 \\
\hline
\end{tabular}

Mean \pm SD values followed by the same letter in each column are not significant different by Tukey's test.

SSR - Sum of squared residuals. $\mathrm{R}^{2}$ - Determination coefficient. $\mathrm{X}^{2}$ - Chi-square.

The rheograms fitted by the Power Law model showed high determination coefficient $\left(\mathrm{R}^{2}\right)$ and low chi-square $\left(\chi^{2}\right)$ values at both temperatures and the $\left(\mathrm{R}^{2}\right)$ values ranged from 0.988 to 0.991 .

It was noticed that F1 and F3 presented higher shear stress compared with F2, F4 and F5, which could be attributed to the higher green banana pulp content in these samples. These formulations presented similar rheological behaviour to commercial mayonnaise, studied by Worrasinchai et al., (2006) which worked at same shear rate 0 to $300 \mathrm{~s}^{-1}$.

The central curves corresponded to the central point samples (F5, F5 1 and $\mathrm{F}_{2}$ ) and according to Tables 3 and 4 there was no statistical difference between the central point samples (F5, F5 1 and
$\mathrm{F}_{2}$ ), indicating small experimental error.

Consistency coefficient $(K)$ values decreased with an increase in temperature for all the formulations. According to Krokida et al (2001), the temperature has a major effect on the consistency coefficient $(K)$ on the non-Newtonian fluid food.

Tables 5 and 6 show the rheological parameters $n$ and $\mathrm{K}$ analysis of variance at 10 and $25^{\circ} \mathrm{C}$, fitted according to the quadratic models. Analysis of variance (F-test) showed that the second order (quadratic) model fitted well into the experimental data. The lack-of-fit tests, which measured the fitness of the model obtained, did not result in a significant F-value, indicating that the model was sufficiently accurate to predict the rheological responses within the ranges studied.

Table 5 - Flow behaviour index (n) and consistency coefficient (K) response analysis of variance at $10^{\circ} \mathrm{C}$ and $25^{\circ} \mathrm{C}$.

\begin{tabular}{lcccccccc}
\hline \multicolumn{1}{c}{ Source } & $\begin{array}{c}\text { Square } \\
\text { sum }\end{array}$ & $\begin{array}{c}\text { Degrees of } \\
\text { freedom }\end{array}$ & $\begin{array}{c}\text { Mean } \\
\text { square }\end{array}$ & $\mathbf{F}$ & $\begin{array}{c}\text { Square } \\
\text { sum }\end{array}$ & $\begin{array}{c}\text { Degrees of } \\
\text { freedom }\end{array}$ & $\begin{array}{c}\text { Mean } \\
\text { square }\end{array}$ & F \\
\hline $\mathrm{n}$ (flow & & & & $10^{\circ} \mathrm{C}$ & & & & $25^{\circ} \mathrm{C}$ \\
behaviour index) & & & & & & & & \\
Model & 0.004 & 4 & 0.005 & $257.75^{*}$ & 0.025 & 4 & 0.006 & $555.89^{*}$ \\
Total error & 0.0003 & 16 & 0.000 & & 0.0002 & 16 & 0.00 & \\
Lack-of-fit & 0.00 & 0 & 0.000 & & 0.00 & 0 & 0.00 & \\
Pure error & 0.0003 & 16 & 0.000 & & 0.0002 & 16 & 0.00 & \\
Total & 0.019 & 20 & 0.000 & & 0.025 & 20 & 0.001 \\
K (consistence & & & & & & & & \\
coefficient) & & & & & & & & \\
Model & 1182.80 & 4 & 295.70 & $6420,73^{*}$ & 864.58 & 4 & 216.14 & $2006.98^{*}$ \\
Total error & 0.737 & 16 & 0.046 & & 1.173 & 16 & 0.1080 & \\
Lack-of-fit & 0.000 & 0 & 0.00 & & 0.00 & 0 & 0.0000 & \\
Pure error & 0.737 & 16 & 0.046 & & 1.173 & 16 & 0.1080 \\
Total & 1183.54 & 20 & 59.18 & & 866.30 & 20 & 43.315 \\
\hline
\end{tabular}

$* \mathrm{p}<=0.05$. 
The fitted equations obtained for the rheological parameters $\mathrm{n}$ and $\mathrm{K}$ at 10 and $25^{\circ} \mathrm{C}$ are shown in Table 7. All fitted equations showed high determination coefficients values (ranging from 0.98 to 0.99 ) and low standard error values (ranging from 0.05 to 4.90 ). The $\mathrm{n}$ and $\mathrm{K}$ contour plots are given in Figs. 3 and 4 at $10^{\circ} \mathrm{C}$ and Figs 5 and 6 at $25^{\circ} \mathrm{C}$. As observed (Fig. 3 and 4), the shear-thinning emulsions character, represented by response $\mathrm{n}$, at both temperatures was highly influenced by the water fraction, which was confirmed by the higher quadratic coefficient value shown in eqns 5 and 7 (Table 7).

With regard to the consistency coefficient (Figs 5 and 6) the interaction between soy oil and green banana pulp resulted in higher $\mathrm{K}$ values, even so, the soy oil fraction had a greater effect on the consistency coefficient when compared to green banana pulp (eqns 6 and 8). Similar results were observed by Ma and Barbosa-Canovas (1994) and Gladwell et al. (1986), who working with mayonnaise, observed that consistency coefficient magnitude increased with oil concentrations. According to Urbanski et al (1982), the emulsions consistency coefficient has a linear relationship with the intumesced polymers. A emulsion, when is compound by polymers, causes large internal frictions, resulting in consistency coefficient $(K)$ raise.

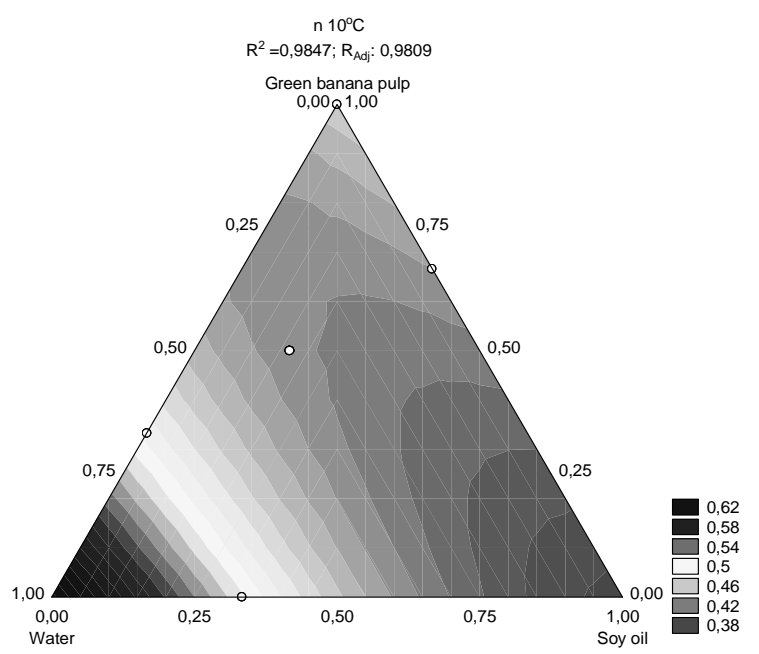

Figure 3 - Flow behaviour index (n) contour plots fitted by the quadratic model at $10^{\circ} \mathrm{C}$.

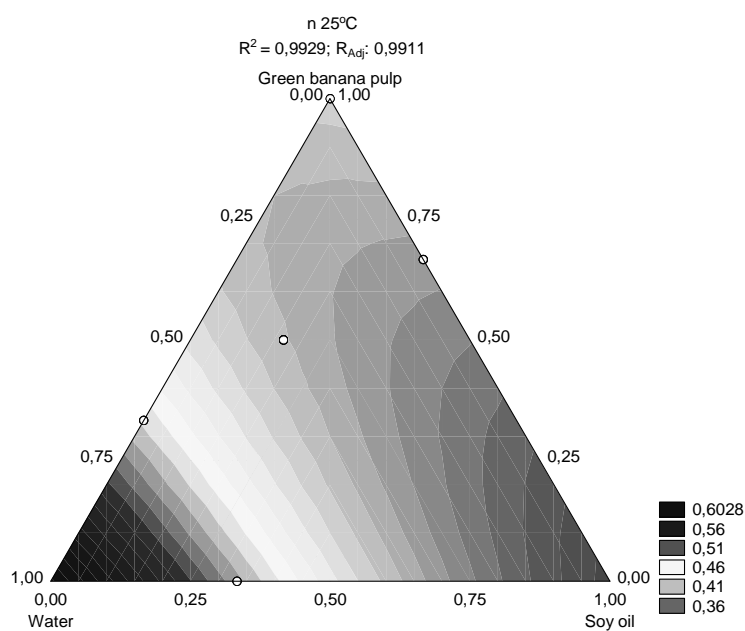

Figure 4 - Flow behaviour index (n) contour plots fitted by the quadratic model at $25^{\circ} \mathrm{C}$. 


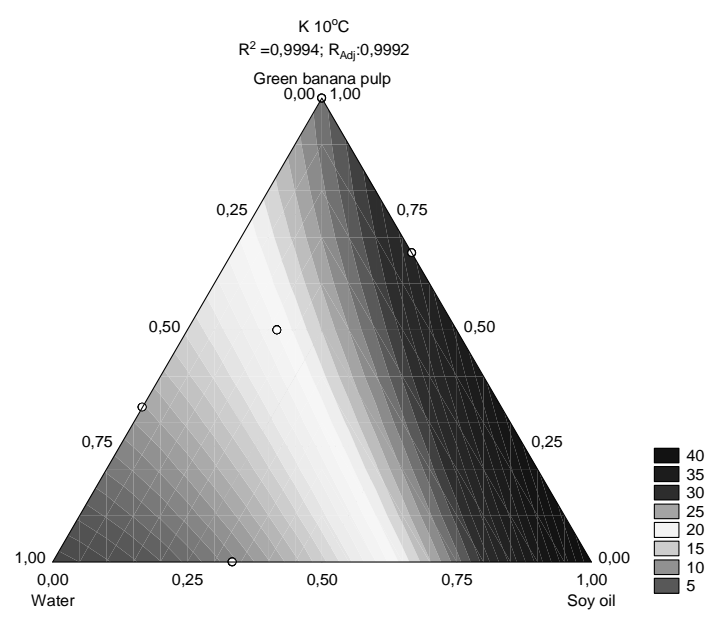

Figure 5 - Consistency coefficient (K) contour plots fitted by the quadratic model at $10^{\circ} \mathrm{C}$.

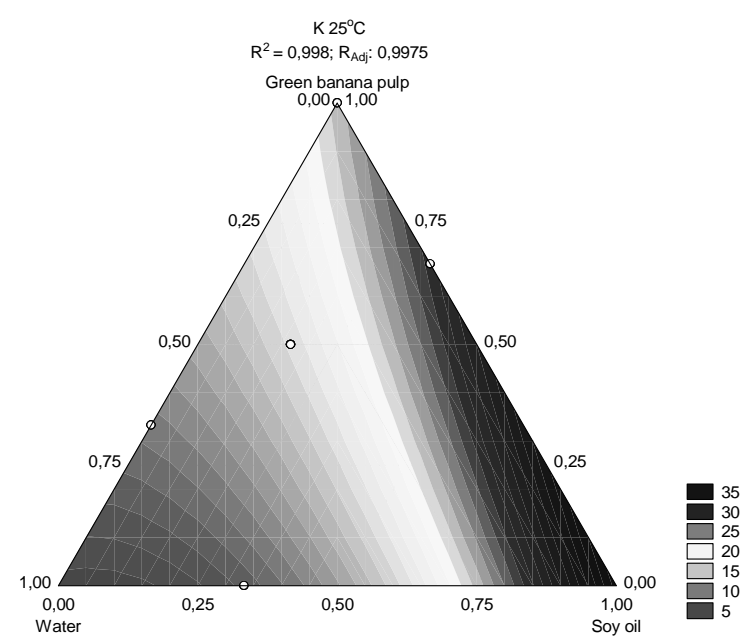

Figure 6 - Consistency coefficient $(\mathrm{K})$ contour plots fitted by the quadratic model at $25^{\circ} \mathrm{C}$.

Table 7 - Rheological parameters ( $\mathrm{n}$ and $\mathrm{k}$ ) regression equations.

\begin{tabular}{|c|c|c|c|}
\hline $\mathrm{T}=10^{\circ} \mathrm{C}($ Eqns 1 and 2$) \mathrm{T}=25^{\circ} \mathrm{C}($ Eqns 3 and 4$)$ & Eqn & $\mathbf{R}^{2}$ & SE \\
\hline $\mathrm{n}=0,63 \mathrm{X} 1 *+0,37 \mathrm{X} 2+0,46 \mathrm{X} 3-0,21 \mathrm{X} 1 \mathrm{X} 2 *-0,40 \mathrm{X} 1 \mathrm{X} 3 *$ & 5 & 0.98 & 0.07 \\
\hline $\mathrm{K}=1,29 \times 1+41,92 \times 2 *+26,67 \times 3 *-27,79 \times 1 \times 2 *+5,00 \times 1 \times 3 *$ & 6 & 0.99 & 4.01 \\
\hline $\mathrm{n}=0,60 \times 1 *+0,32 \times 2+0,41 \times 3-0,12 \times 1 \times 2-0,33 \times 1 \times 3$ & 7 & 0.99 & 0.05 \\
\hline $\mathrm{K}=4,53 \times 1+37,52 \times 2 *+22,47 \times 3 *-36,86 \times 1 \times 2 *-4,12 \times 1 \times 3 *$ & 8 & 0.99 & 4.90 \\
\hline
\end{tabular}

* significative coefficients.

$\mathrm{SE}=$ Standard Error, $\mathrm{R}^{2}=$ Determination Coefficient; $\mathrm{X} 1$ = water; $\mathrm{X} 2$ = oil; $\mathrm{X} 3$, green banana pulp.

Apparent viscosity plot versus shear rate at 10 and $25^{\circ} \mathrm{C}$ are shown in Figs. 7 and 8. All the formulations apparent viscosity decreased as the temperature and shear rate increased. This behaviour could be explained by the molecules structural breakdown due to the hydrodynamic forces generated and the increased constituent molecules alignment (Asparlan and Haita, 2002; Rao and Tattyakul, 1999). Small hydrodynamic forces at low shear rate are not able to disrupt the flocks and as an effect of shear rate increases, the hydrodynamic forces dominate and disrupt the 
flocks, causing a viscosity reduction (McClements, 1999).According to Haminiuk et al. (2007), during food processing, the food structure become weak as temperature increases. Similar results were also obtained to fruit pureés by Guerrero and Alzamora (1997, 1998).

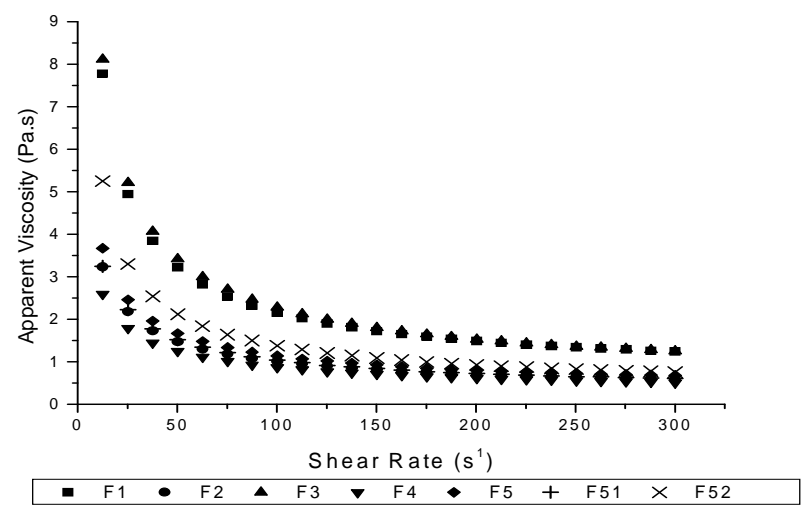

Figure 7 - Apparent viscosity at $10^{\circ} \mathrm{C}$.

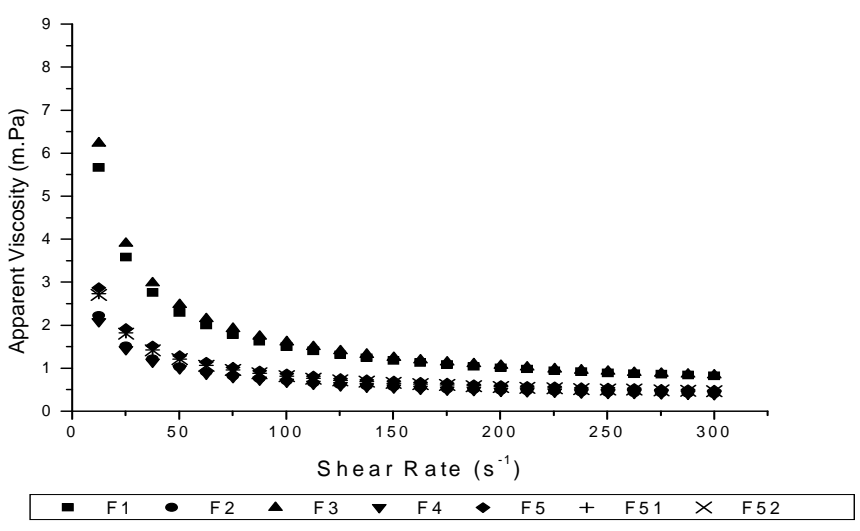

Figure 8 - Apparent viscosity at $25^{\circ} \mathrm{C}$.

\section{Optical microscope observation}

In Fig. 9a-e., the emulsions microstructures in the same day that they were prepared are verified.

The small drops correspond to the oil and the empty spaces and according to Worrasinchai et al., (2006) represent the continuous phase, that is, the watery phase. In this work, due to the drops sizes, the all formulations in the first day were steady, therefore, did not have drops coalescence signal.The formulations $\mathrm{F} 1$ and $\mathrm{F} 3$ presented bigger drops and were more uniform than the others formulations, being able to be classified in accordance with Worrasinchai et al., (2006) as monodispersed emulsions (uniformity in the drops size), whereas, F2, F4 and F5 presented small variety in the drops size (polydispersed). Gutierrez et al., (2002) found that the monodispersed emulsions presented significantly bigger viscosity than polydispersed Emulsions. The same was found in this work through the rheological analyses where the emulsions F3 and F1 presented higher viscosity. Fig. 10a-e show the emulsions microstructures after 60 days storage at $10^{\circ} \mathrm{C}$. 


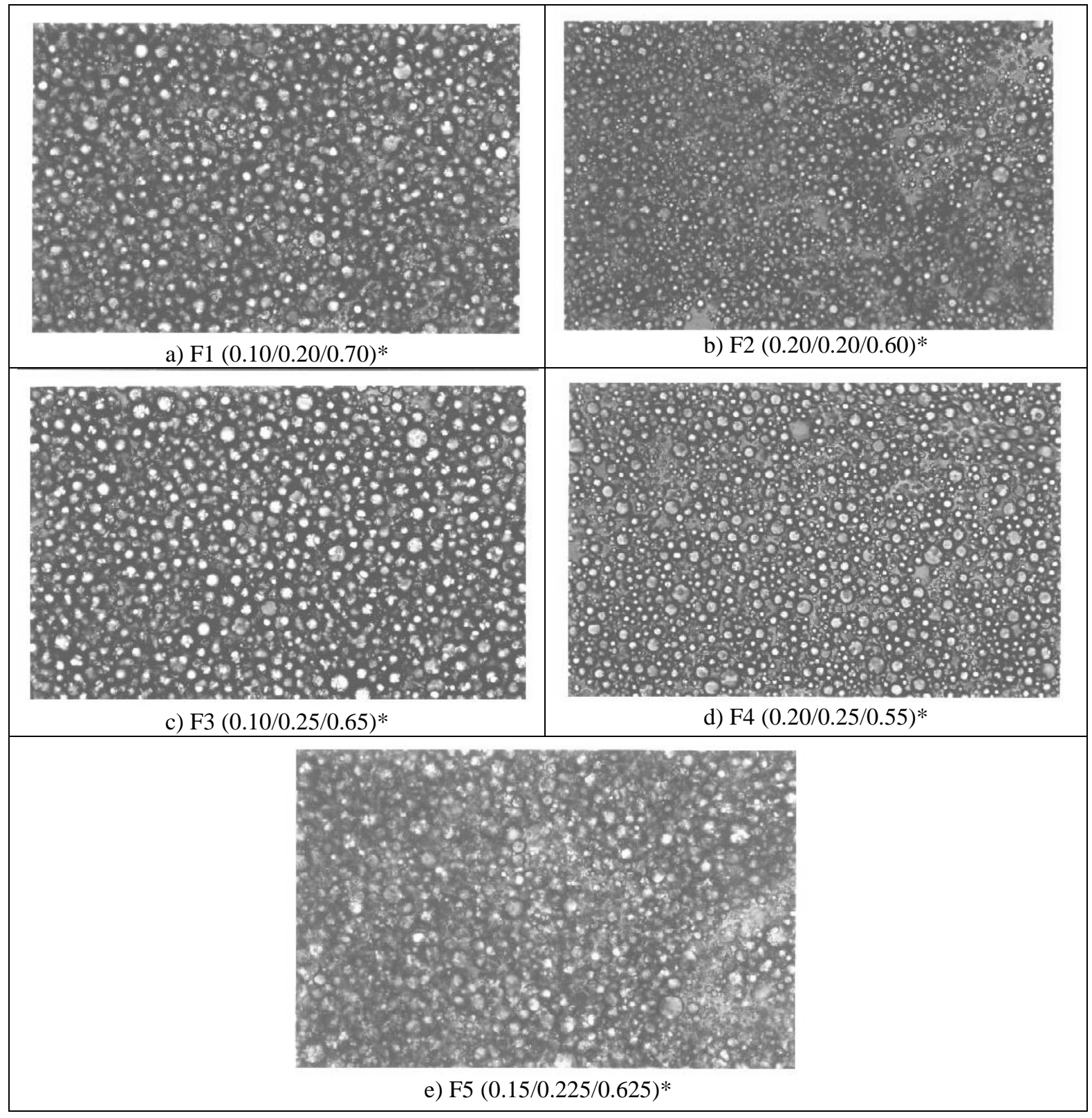

Figure 9 - Microstructures at 40X to F1 (a), F2 (b), F3 (c), F4 (d) and F5 (e) at first day * water/soy oil/ green banana pulp proportions. 


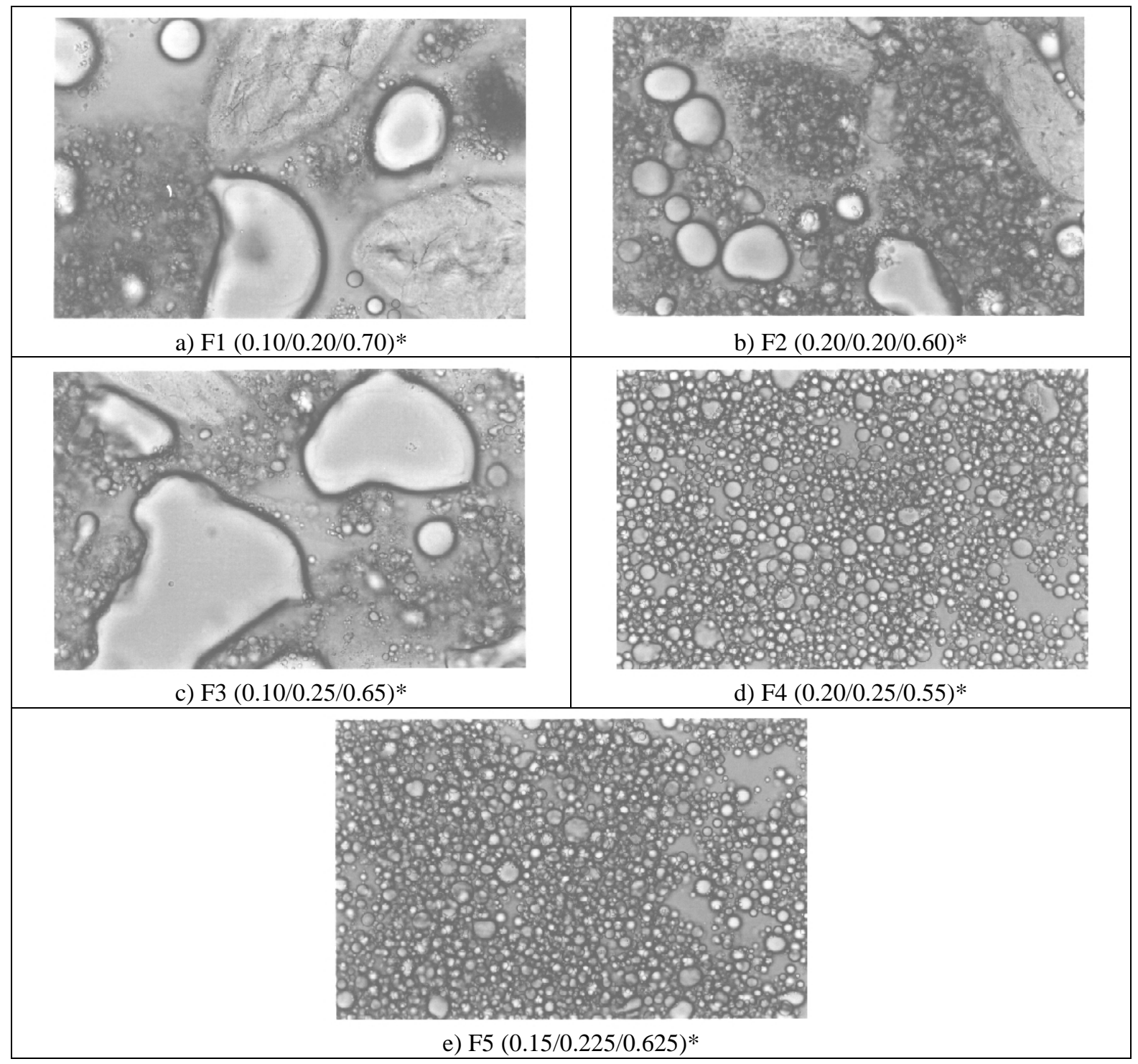

Figure 10 - Microstructures at 40X to F1 (a), F2 (b), F3 (c), F4 (d) and F5 (e) afters 60 days of preparation.* water/soy oil/ green banana pulp proportions.

After two months F5 and F4 remained steady (Figs. 10d and 10e) and creamy, F2 on the other hand presented notables coalescence signals with consequent instability (Fig 10b). As observed in Figs 10a and $\mathrm{c}$ the F1 and F3 formulations were totally unstable with great coalescence signals (large water drops). This could be attributed to the microbiological deterioration of the product. However, there was not a phase separation in both the formulations. In mayonnaises added to $\beta$ glucan as fat substitute, Worrasinchai et al., (2006) observed that the formulation without $\beta$-glucan presented biggest drops size and was uniform (monodispersed), and the formulation with $25 \% \beta$ - glucan presented polydispersed, where small drops were between the big ones.

\section{CONCLUSIONS}

From the present work, it could be concluded that in all the formulations, the mixtures presented shear-thinning (pseudoplastic) behaviour and the rheological parameters were well represented by the Power Law model. With an increase in temperature, a decrease in flow behaviour index (n) and consistency coefficient $(\mathrm{K})$ were observed. Good fit models were developed for flow 
behaviour index and consistency coefficient. The formulations with higher GBP content, 70 and $65 \%$ (F1 and F3, respectively) were the ones that presented higher shear stress and apparent viscosity. RSM studies showed that the interaction between the soy oil and green banana pulp contributed to the consistency coefficient $(\mathrm{K})$ increase to all the samples. Water, on the other hand, acted on the flow behaviour index (n) increase. Analysis of variance showed that the second-order model had not significant lack-of-fit and a significant F-value, indicating that quadratic model fitted well into the experimental data. The emulsions that presented better stability were the formulations F4 with 55\% green banana pulp, 20\% water and $25 \%$ soy oil and the formulation F5 with $62,5 \%$ green banana pulp, $15 \%$ water and $22.5 \%$ soy oil.

\section{RESUMO}

No presente trabalho, foi estudado o comportamento reológico de emulsões adicionadas de polpa de banana verde utilizando a metodologia de superfície de resposta e também foram investigadas a estabilidade das emulsões. Foram desenvolvidas cinco formulações, de acordo com o delineamento para superfícies limitadas e misturas, com as proporções respectivamente: água/óleo de soja/polpa de banana verde: F1 $(0,10 / 0,20 / 0,70)$, F2 $(0,20 / 0,20 / 0,60), \quad F 3 \quad(0,10 / 0,25 / 0,65), \quad$ F4 $(0,20 / 0,25 / 0,55)$ e F5 $(0,15 / 0,225 / 0,625)$. As propriedades reológicas foram realizadas em reômetro Haake Rheostress 600, com sensor de geometria cone e placa $\left(60-\mathrm{mm}\right.$ diâmetro, $2^{\circ}$ ângulo de cone), usando uma distância de abertura de $1 \mathrm{~mm}$. As emulsões mostraram comportamento pseudoplástico e foram descritas adequadamente pelo modelo Lei da Potência. O comportamento reológico foi influenciado pelas diferentes proporções de polpa de banana verde e também pelas temperaturas $\left(10\right.$ e $\left.25^{\circ} \mathrm{C}\right)$. As formulações com alto teor de polpa (F1 e F3) apresentaram maior tensão de cisalhamento e viscosidade aparente. Relativo à metodologia de superfície de resposta, descrita pelo modelo quadrático, pôde-se observar que o coeficiente de consistência aumentou com a interação entre a polpa de banana verde e a concentração de óleo de soja e a água contribuiu com $\mathrm{o}$ aumento do índice de comportamento para todas as amostras de emulsões. A Análise de Variância mostrou que o modelo de segundo ordem não apresentou faltade-ajuste com valor $\mathrm{F}$ significativo, indicando que o modelo quadrático representou bem os dados experimentais. As emulsões que apresentaram melhor estabilidade foram as formulações $\mathrm{F} 4$ $(0,20 / 0,25 / 0,55)$ e F5 $(0,15 / 0,225 / 0,625)$.

\section{REFERENCES}

Anonymous (2002), Importation of bananas from the Philippines. Technical Information Paper Part 5 of 5. Agriculture, Fisheries and Forestry Australia.

AOAC (2000), Official methods of analysis, $15^{\text {th }}$ edn. Washington, DC: Association of Official Analytical Chemists.

Asparlan, M., Haita, M. (2002), Rheological and sensory properties of pekmez (grape molasses/tahin) (sesame paste blands). Journal of Food Engineering, 54, 89-93.

Batista A. P., Raymundo A., Sousa I., and Empis J. (2006), Rheological characterization of coloured oilin-water food emulsions with lutein and phycocyanin added to the oil and aqueous phases. Food Hydrocolloids, 20, 44-52.

Biazus, J. P. M.: Souza, A. G.; Santana, J. C. C. Souza, R. R.; Tambourgi, E. B. (2005), Optimization of drying process of Zea mays malt to use as alternative source of amylolytics enzymes. Brazilian Archive of Biology and Technology,48 (6), 185-190

Borges, M. T. M. R. (2003), Potencial vitamínico de banana verde e produtos derivados. (pp.137). Ph.D. thesis. Campinas, Brasil: Universidade Estadual de Campinas (UNICAMP), Faculdade de Engenharia (FEA).

Branco, I. G. and Gasparetto, C. A. (2003), Response surface methodology applied to the study of temperature effect on the rheological behaviour of ternary mixtures with mango pulp and orange and carrot juices. Ciência e Tecnologia de Alimentos, 23, 166-171.

Cornell, J. A. (2002), Experiments with mixtures: designs, models and the analysis of mixture data. $3^{\text {rd }}$ ed. New York, p. 21-99.

Ferreira, G. B. Evangelista' A. F. Severo Junior J. B.; Souza, R. R. Santana, J. C. C Tambourgi, E. B. Jordão E. .(2007), Partitioning optimization of proteins from Zea mays malt in ATPS PEG 6000/CaCl2. Brazilian Archives of Biology and Technology.50 (3), 557-564.

Gladwell, N., Rahalkar, R. R. and Richmond, P. (1986), Influence of disperse phase concentration upon the viscoelastic behaviour of emulsions. Rheology Acta, 25, 55-61.

Guerrero, S. N., and Alzamora S. M. (1998), Effect of $\mathrm{pH}$, temperature and glucose addition on flow behaviour of fruit purées II. Peach, papaya and 
mango purées. Journal of Food Engineering, 37, 77101.

Guilmineau F., Kulozik, U. (2007), Influence of a thermal treatment on the functionality of hen's egg yolk in mayonnaise. Journal of Food Engineering doi:10.1016/j.jfoodeng.

Gutierrez, X., Silva, F., Chirinos, M., Leiva, J., and Rivas, H. (2002), Bitumen-in-water emulsion: An overview on formation, stability and rheological properties. Journal of Dispersion Science and Technology, 23, 405-418.

Haminiuk, C. W. I., Sierakowski, M-R., Branco I. G., Maciel, G. M., and Masson, M. L. (2007). Rheological study of ternary mixtures and pectic gels of red fruit pulps. Journal of Food Science and Technology. 42, 629-639.

Higuti, I. H.; Silva, P. A. Papp, J.; Okiyama, V. M. O.; Andrade, E. A.; Marcondes. A. A. and Nascimento, A. J.(2004), Colorimetric determination of and cyclodextrins and studies on optimization of CGTase production from $B$. firmus using factorial designs. Brazilian Archives of Biology and Technology, 47 (6), 837-841.

Krokida, M. K., Maroulis, Z. B., and Saravacos, G. D. (2001). Rheological properties of fluid fruit and vegetable purée products: compilation of literature data. International Journal of Food Properties, 4 (2), 179-200.

Krzysztof N. W Aparicio M.A Bello L.A. Monroy J.A.(2003), Changes of banana starch by chemical and physical modification. Carbohydrate polymers. 52 (3), 237-242.

Instituto Brasileiro de Geografia e Estatística (IBGE). Levantamento sistemático da produção agrícola. Set. $2006 . \quad$ Avaible in: <http://www.sidra.ibge.gov.br/bda/prevsaf/default.as $\mathrm{p} ? \mathrm{z}=$ tando $=10$ andi $=\mathrm{P}>$. Acessed in: 05 de fevereiro de 2007

INIBAP (International Network for the Improvement of Banana and Plantain). (2002), Net Working Banana and Plantain: INIBAP Annual Report 2001, Montpelier, France.

Instituto Adolfo Lutz (IAL). (2005), Me'todos f1'sicoquímicos para ana lise de alimentos. 4th ed. Brasília, Brasil..

Izidoro D. R. I. (2007), Influência da polpa de banana (musa cavendishii) verde no comportamento reológico, sensorial e físico-químico de emulsão. Masther's thesis. Federal University of Paraná, Curitiba-Pr, Brazil. 147p.

Lima L. C., Costa, S. M. Dias, M. S. C., Martins, R. N., Ribeiro Jr, P. M. (2004), Controle do amadurecimento de banana 'prata-anã', armazenada sob refrigeração e atmosfera modificada passiva com o uso do 1-metilciclopropeno. Ciência $e$ Agrotecnologia, Lavras-MG, Brazil, 29 (2), 476-480.

Liu, H., Xu, X.M., Guo, Sh.D. Rheological, texture and sensory properties of low-fat mayonnaise with different fat mimetics, (2007). LWT- Food technology. 40, 948 ,946-954.

Ma, 1., and Barbosa-Canovas. G. V. (1994), Rheological characterization of mayonnaise. Part 1: Slippage at Different Oil and Xanthan Gum concentrations. Journal of Food Engineering, 25 (3), 397-408.

Ma, L., and Barbosa-Canovas. G. V. (1995), Rheological characterization of mayonnaise. Part 2: flow and viscoelastic properties at different oil and xanthan gum concentration. Journal of Food Engineering, 25 (3), 409-425.

Mcclements, D. J. (1999), Food Emulsions: Principles, Practice, and Techniques, CRC Press, Boca Raton. p. 378.

Morton, J. F. (1987), Fruits of warm climates. Banana. Miami. Florida. p. 29-46.

Peressini, D., Sensidoni A., Ciondio B. (1998). Rheological characterization of traditional and light mayonnaises. Journal of Food Engineering , 35, 409-417.

Rao, M. A. and Tattiyakul, J. (1999), Granule size and rheology behaviour heated tapioca starch dispersions. Carbohydrate Polymers, 38, 123-132.

Silva, C. S., Lima L. C., Santos, H. S., Camili, E. C., Vieira, C. R. Y. I., Martin C. S., Vieites, R. L. (2006). Amadurecimento da banana-prata climatizada em diferentes dias após a colheita. Ciência $e$ Agrotecnologia. Lavras, 30 (1), 103-111.

Souci, S. W., Fachman, W., and Kraut, H. (2000). Food composition and nutrition tables $\left(6^{\text {th }}\right.$ Ed.). Stuttgart: Medpharm.

Urbanski, G. E., Wei, L. S., Nelson, A. I., Steinberg, M.P. (1982). Rheology and water imbibing of major fractions of soybean beverage. Journal of Food Science, Chicago, 47 (3), 1021-1022.

USP - Universidade Estadual de São Paulo. Tabela de composição de alimentos. Projeto integrado de composição de alimentos. Avaible in: http://www.fcf.usp.br/tabela/tbmenu.php. Acessed: 16/01/07.

Valle, H. F., and Camargos, M. (2003), Yes, nós temos banana. Editora Senac. São Paulo.

Worrasinchai S., Suphantharika M., Pinjai S., and Jamnong P. (2006), $\beta$-Glucan prepared from spent brewer's yeast as a fat replacer in mayonnaise. Food Hydrocolloids, 20, 68-78.

Zhang, P., Whistler, R. L., BeMiller, J. N., and Hamaker, B. R. (2005), Banana starch: production, physicochemical properties, and digestibility - a review. Carbohydrate Polymers, 59, 443-458.

Received: May 28, 2007; Revised: February 07, 2008; Accepted: April 27, 2009. 